\title{
Neuritin inhibits astrogliosis to ameliorate diabetic cognitive dysfunction
}

\author{
Zuo Zhang*, Hongli Zhou* and Jiyin Zhou DD \\ National Drug Clinical Trial Institution, Second Affiliated Hospital, Army Medical University, Chongqing, China \\ Correspondence should be addressed to J Zhou: zhoujiyin@gmail.com \\ *(Z Zhang and H Zhou contributed equally to this work)
}

\begin{abstract}
Earlier, it was shown that reversing the downregulation of neuritin expression in the brain improves central neuropathy in diabetic rats. We investigated the protective mechanism of neuritin in diabetic cognitive dysfunction via astrocytes. Further, the impact of the overexpression of neuritin in the cortex and the hippocampus on diabetic cognitive dysfunction and astrogliosis in type 2 diabetic $(\mathrm{db} / \mathrm{db})$ mice was assessed. Antagonists were used to inhibit the JAK2/STAT3 signaling pathway in U-118MG, an astrocyte cell line. Immunofluorescence, Western blotting, and real-time PCR were performed. Neuritin overexpression in the hippocampus of $\mathrm{db} / \mathrm{db}$ mice significantly ameliorated cognitive dysfunction, hippocampal neuronal impairment, and synaptic plasticity deterioration, and inhibited astrogliosis and the JAK2/STAT3 signaling pathway in the hippocampus. Neuritin suppressed the JAK2/STAT3 signaling pathway to inhibit lipopolysaccharide-induced gliosis in U-118MG cells. It was observed that neuritin regulates the JAK2/STAT3 signaling pathway in astrocytes to inhibit astrogliosis and improve diabetic cognitive dysfunction.
\end{abstract}

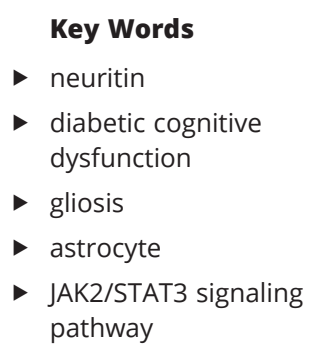

Journal of Molecular Endocrinology (2021) 66, 259-272

\section{Introduction}

The incidence of cognitive dysfunction in patients with type 2 diabetes is 1.5 times higher than that in nondiabetic patients and 60 to $70 \%$ of diabetes patients have cognitive dysfunction. Currently, the management strategies for type 2 diabetes cannot benefit cognitive dysfunction, which place a great burden on type 2 diabetes, their families, and society (Yuan \& Wang 2017). Progressive cognitive dysfunction is a central characteristic of diabetic encephalopathy ( $\mathrm{Xu}$ et al. 2017). Prediabetes is linked to structural brain abnormalities, with further exacerbation of type 2 diabetes (van Agtmaal et al. 2018). Impaired cognition during type 2 diabetes is particularly evident in the scope of memory and executive function (Areosa Sastre et al. 2017).
Hippocampal synaptic plasticity is the neurobiological basis of learning and memory in cognitive function and participates in the occurrence and development of cognitive dysfunction in type 2 diabetes (Huang et al. 2016). Hippocampal synaptic plasticity is regulated by several neurotrophic factors, including neuritin (An et al. 2014). Astrocytes not only bridge the gap between metabolic supplies by blood vessels and neurons but also allow the fine control of neurotransmission by providing appropriate signaling molecules and insulation through tight enwrapping of synapses (Dallerac \& Rouach 2016). Abnormalities in synaptic transmission lead to cognitive dysfunction (Koyama 2014). Astrocytes play an important role in cognitive functions, including learning and

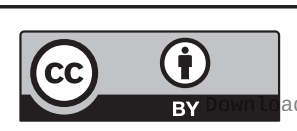

This work is licensed under a Creative Commons Attribution 4.0 International License. 
memory (Santello et al. 2019). Reactive gliosis is a process in which astrocytes maintain the stability of the neuronal microenvironment and play a protective role in the early stage of the injury, but persistent reactive gliosis forms a glial scar at the injury site to repair the missing site and further block the nerve. Diabetic rats display astrogliosis in the cortex and hippocampus (Tomassoni et al. 2013); while type 2 diabetic mice also show synaptic dysfunction and astrogliosis with memory impairment (Duarte et al. 2012).

Scar formation in astrocytes after spinal injury is regulated by the STAT3 signaling pathway (Wanner et al. 2013). The JAK2/STAT3 signaling pathway is involved in several diabetic complications, such as diabetic neuropathy (Li et al. 2019), diabetic cardiomyopathy (Gao et al. 2019), and diabetic nephropathy (Wang et al. 2012). The JAK2/STAT3 signaling pathway in the hippocampus of diabetic rats induced by streptozotocin is one of the most significant signaling pathways that regulates the process during such complications (Gurzov et al. 2016). The JAK2/STAT3 signaling pathway is involved in environmental contaminant-mediated astrocyte activation (Chen et al. 2018) and is necessary and sufficient to induce and maintain astrocyte reactivity (Ceyzeriat et al. 2018). Over the years, the JAK2/STAT3 signaling pathway has emerged as a central regulator of astrocyte reactivity and plays a critical role in animal models that regulate synaptic plasticity, reactive gliosis, and cognitive dysfunction (Ceyzeriat et al. 2016).

Neuritin (also named cpg15) is an activity-induced glycosylphosphatidylinositol-anchored axonal protein that is mainly expressed in the brain (Zhou \& Zhou 2014). Neuritin ameliorates neurite outgrowth recovery of hippocampal neurons after mouse cerebral ischemia (Zhao et al. 2017) and improves depression and cognitive function during schizophrenia (Son et al. 2012). Nerve growth factor treatment restores neuritin levels in the dorsal root ganglia and sciatic nerves of diabetic rats (Karamoysoyli et al. 2008). In a previous study, we showed that berberine benefits diabetic neuropathy by improving micropathology and increasing neuritin expression via the mitogen-activated protein kinase signaling pathway (Zhou et al. 2016). Administration of exogenous neuritin improves the viability and function of Schwann cells in diabetic neuropathy rats (Xi et al. 2020).

In the present study, we employed the overexpression of neuritin in the cortex and hippocampus of type 2 diabetic $(\mathrm{db} / \mathrm{db})$ mice and lipopolysaccharide induction of U-118MG astrocyte cell line to investigate the effects of neuritin on diabetic cognitive dysfunction and astrogliosis through the JAK2/STAT3 signaling pathway.

\section{Material and methods}

\section{$\mathrm{db} / \mathrm{db} /$ neuritin/Emx1-Cre mice}

A transgenic mouse line harboring the CMV-LoxP-STOPLoxP-tagged human neuritin transgene was established using C57BL/6J mice generated by Cyagen Biosciences Inc. ((Guangzhou, China) Certificate No. TGBS141013BA1). A transgenic mouse model with high cortical and hippocampal tissue-specific overexpression of neuritin was established by crossing neuritin transgenic mice with Emx1-Cre mice (B6.129S2Emx1 ${ }^{\text {tm1(cre) }} \mathrm{Krj} / \mathrm{J}$, https://www. jax.org/strain/005628). C57BL/6J-Leprdb/+ heterozygous littermate $(\mathrm{db} / \mathrm{m})$ mice were purchased from the Jackson Laboratory (Stock Number: 000699). Nondiabetic $\mathrm{db} / \mathrm{m}$ mice were used to crossbreed C57BL/6J-Leprdb/db diabetic $(\mathrm{db} / \mathrm{db})$ mice. The $\mathrm{db} / \mathrm{m}$ mice were crossed with the neuritin-Cre transgenic mice to yield $\mathrm{db} / \mathrm{db} /$ neuritin/ Exm1-Cre (neuritin overexpression $\mathrm{db} / \mathrm{db}$ ) mice, which are triple transgenic diabetic mice overexpressing neuritin in the cortex and hippocampus. All mice were backcrossed onto the $\mathrm{C} 57 \mathrm{BL} / 6 \mathrm{~J}$ background for ten generations. Cre-mediated excision of neuritin was assessed by PCR using genomic DNA derived from the tail. In all animal studies, male mice were used, and littermates served as controls. All mice were bred in a specific pathogen-free, temperature-and humidity-controlled environment with a $12 \mathrm{~h}$ light: $12 \mathrm{~h}$ darkness cycle and allowed free access to food and water. The animal experiments were approved by the Army Medical University according to the guidelines of the Institutional Animal Care and Use Committee.

\section{Drug treatment}

Both standard and high-fat diets containing $45 \%$ fat were purchased from Mediscience Ltd., Nanjing, China. The high-fat diet contained $24.0 \%$ protein, $41.0 \%$ carbohydrate, and $24.0 \%$ fat. Six-week-old male mice were separated into four groups, with six animals per group. One group of mice was fed a standard diet, while the other groups were fed a high-fat diet instead of a standard diet for 8 weeks. (i) $\mathrm{db} / \mathrm{m}$ mice were fed a standard diet, (ii) $\mathrm{db} / \mathrm{db}$ mice fed a high-fat diet, (iii) neuritin-overexpressing $\mathrm{db} / \mathrm{db}$ mice fed a high-fat diet, (iv) db/db mice fed a high-fat diet+JAK2 inhibitor (AG490, $15 \mathrm{mg} / \mathrm{kg}$, Abcam, Catalog \#ab120950). During the 8 weeks of treatment, the mice were intraperitoneally injected with JAK2 inhibitor or its dilution vehicle (PBS containing 5\% dimethyl sulfoxide) (Ignarro et al. 2013).

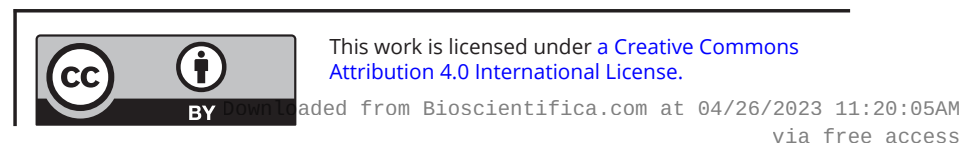




\section{Morris water maze test}

After 7 weeks of drug administration, the animals were tested in a spatial version of the Morris water maze test as previously described (Si et al. 2016). The Morris water maze consisted of a circular water tank $(120 \mathrm{~cm}$ diameter, $50 \mathrm{~cm}$ height) that was partially filled with water $\left(25^{\circ} \mathrm{C}\right)$. Milk powder was used to render the water opaque. The training started by acclimating the mouse to the task environment with 2 days of free-swimming in the pool with no platform. Each session lasted for $2 \mathrm{~min}$. The pool was virtually divided into four equal quadrants, labeled as N-S-E-W. A platform (10 cm diameter) was placed in one of the four maze quadrants (the target quadrant) and submerged $0.5 \mathrm{~cm}$ below the water surface. The platform remained in the same quadrant throughout the experiment. The mice were required to find the platform using only the distal spatial cues available in the testing room. The cues were maintained throughout the time of the test. The mice received four consecutive daily training trials in the following 5 days, with each trial having a ceiling time of $60 \mathrm{~s}$ and a trial interval of approximately 30 s. The mouse had to swim until it climbed onto the platform and then submerged beneath the water. After climbing onto the platform, the animal remained there for $30 \mathrm{~s}$ before the commencement of the next trial. The escape platform was kept at the same position relative to the distal cues. If the mouse failed to reach the escape platform within the maximum allowed time of $60 \mathrm{~s}$, it was gently placed on the platform and allowed to remain there for the same amount of time. The time taken to reach the platform (latency in seconds) was measured.

A probe trial was performed to assess the extent of memory consolidation. The time spent in the target quadrant indicates the degree of memory consolidation that occurs after learning. In the probe trial, the mouse was placed into the pool as in the training trial, except that the hidden platform was removed from the pool. The time of crossing the former platform quadrant and the total time of crossing all quadrants were recorded for $60 \mathrm{~s}$.

\section{Tissue preparation}

After the Morris water maze test, mice were allowed to recover for a day, then fasted overnight, and were anesthetized with chloral hydrate (ip, $400 \mathrm{mg} / \mathrm{kg}$ ). Blood of mice from each group was collected from the heart, transferred immediately into microcentrifuge tubes, and allowed to clot to obtain the serum. It was then perfused with $0.9 \%$ sodium chloride solution containing
$0.1 \%$ diethylpyrocarbonate at $25^{\circ} \mathrm{C}$ followed by $4 \%$ paraformaldehyde in $0.1 \mathrm{~mol} / \mathrm{L}$ PBS. After removing from the skull, the brains were fixed in 4\% paraformaldehyde overnight, dehydrated in a 30\% sucrose solution for 3-5 days at $4^{\circ} \mathrm{C}$. Serial coronal sections $(25 \mu \mathrm{m}$ thick) of the whole hippocampus were cut using a sliding microtome and stored at $-20^{\circ} \mathrm{C}$ until used for Nissl and immunofluorescence staining. The same sequence number section of serial sagittal sections of the brain containing the hippocampus was used for each experiment.

\section{Nissl staining}

The frozen sections were fixed with $70 \%$ ethanol for $30 \mathrm{~s}$ and rinsed in DEPC-treated water for $30 \mathrm{~s}$. The sections were then stained with 1\% toluidine blue dye for $10 \mathrm{~min}$ at room temperature. After washing in distilled water for $1 \mathrm{~min}$, the sections were dehydrated in a gradient alcohol and mounted with neutral resins. Nissl substance was observed under a light microscope (Olympus) with live neurons being highlighted by blue staining ( $\mathrm{Su}$ et al. 2017). ImageJ 1.50 (National Institutes of Health) was used to analyze the average gray value of images.

\section{In vitro U-118MG cells experiment}

U-118MG cells were maintained in a humidified incubator with $5 \% \mathrm{CO}_{2}$ and maintained at $37^{\circ} \mathrm{C}$ in Dulbecco's modified Eagle's medium (DMEM), supplemented with $10 \%$ fetal bovine serum. Recombinant human neuritin (Sigma Co. Ltd.), JAK2 inhibitor (AG490), and STAT3 inhibitor (Stattic, Abcam Catalog \#ab120952) were administered $30 \mathrm{~min}$ before stimulation with $1 \mu \mathrm{g} / \mathrm{mL}$ lipopolysaccharide. After $48 \mathrm{~h}$ of treatment, cells were collected and lysed, and cell extracts were analyzed by real-time PCR and Western blotting.

\section{Immunofluorescence staining}

Enzymatic retrieval was performed by incubating the sections in proteinase $\mathrm{K}$ for $10 \mathrm{~min}$ at $25^{\circ} \mathrm{C}$. The sections were rinsed with PBS, permeabilized with $0.3 \%$ Triton X-100 in PBS for 30 min, blocked using blocking buffer (PBS containing 5\% normal serum and 0.3\% Triton $\mathrm{X}-100)$ for $1 \mathrm{~h}$, and incubated with primary antibodies $\left(4^{\circ} \mathrm{C}, 12 \mathrm{~h}\right)$ and secondary antibodies $\left(37^{\circ} \mathrm{C}, 2 \mathrm{~h}\right)$ in PBS containing $0.05 \%$ Tween 20 . The primary antibodies used were as follows: GFAP (1:100, Abcam, Catalog \#ab7260), JAK2 (1:100, Abcam, Catalog \#ab108596), p-JAK2 (1:100, Abcam, Catalog \#ab32101), STAT3 (1:100, Abcam,

This work is licensed under a Creative Commons
Attribution 4.0 International License.
BY


Catalog \#ab68153), p-STAT3 (1:100, Abcam, Catalog \#ab76315), and neuritin (1:100, Abcam, Catalog \#64186). The secondary antibodies Alexa 488-labeled goat antirabbit IgG (1:500, Catalog\#A0423) and Alexa 647-labeled goat anti-rabbit IgG (1:500, Catalog\#A0468) were purchased from Beyotime (Shanghai, China). Nuclei were stained with DAPI (Beyotime). Finally, slides were washed five times in PBS and coverslips were mounted in 90\% glycerol for microscopic analysis.

\section{Western blot}

The cortex and hippocampus of the mice were dissected on ice. The proteins in the cortex, hippocampus, and U-118MG cells were extracted using RIPA lysis buffer (Beyotime, Catalog \#P0013B), and total proteins in the supernatant were determined using a BCA protein assay kit (Beyotime, Catalog \#P0012). Then, $40 \mu \mathrm{g}$ of protein was mixed in a buffer (25\% glycerol, 2\% SDS, $0.01 \%$ bromophenol blue, Tris- $\mathrm{HCl}, \mathrm{pH}$ 6.8) and heated at $100^{\circ} \mathrm{C}$ for $5 \mathrm{~min}$. The samples were subjected to $10 \%$ SDS-PAGE, followed by transfer onto a PVDF membrane (Roche) using the GelDoc XR system (Bio-Rad) (Tang et al. 2017). The membrane was washed with Tris-buffered $154 \mathrm{mmol} / \mathrm{L} \mathrm{NaCl}$ solution with $0.1 \%$ Tween 20, and incubated with anti-rabbit neuritin (Abcam, Catalog \#64186), GFAP (Abcam, Catalog \#ab7260), JAK2 (Abcam, Catalog \# ab108596), p-JAK2 (Abcam, Catalog \#ab32101), STAT3 (Abcam, Catalog \#ab68153), p-STAT3 (Abcam, Catalog \#ab76315), or $\beta$-actin polyclonal antibody (100 in dilution, Sigma, Catalog \#A2103) for $1 \mathrm{~h}$ at $25^{\circ} \mathrm{C}$, and incubated with peroxidase-conjugated anti-rabbit IgG (1:1000) for $1 \mathrm{~h}$ at $25^{\circ} \mathrm{C}$. After the reaction, proteins were visualized with an ECL kit and images were obtained using ImageQuant LAS4010 (GE Healthcare). Samples were run in duplicate for each experiment. Densitometry analysis of the images was performed using Image 1.50 .

\section{Real-time PCR}

Total RNA from the cortex, hippocampus, and U-118MG cells was extracted using RNAiso Plus (TAKARA, Catalog\#9108/9109) (Tang et al. 2017). cDNA was synthesized using a Reverse-Transcription Reagent Kit (TAKARA, Catalog\#RR047A) (Tang et al. 2017). Real-time PCR measurements of individual cDNAs were performed using SYBR Premix Ex Taq ${ }^{\mathrm{TM}}$ II (TAKARA, Catalog\#RR820A) to measure the duplex DNA formation with the ABI Prism 7500 Sequence Detection System (Applied Biosystems) (Tang et al. 2017), normalized to the amount of $\beta$-actin RNA and analyzed by the $2^{-\Delta \Delta C T}$ method (Livak \& Schmittgen 2001). The following primers were used: $\beta$-actin sense 5-CTCTAGACTTCGAGCAGGAGAT-3; $\beta$-actin antisense 5-CAGGATTCCATACCCAAGAAGG-3; neuritin sense 5-GCGGTGCAAATAGCTTACCTG-3, neuritin antisense 5-CGGTCTTGATGTTCGTCTTGTC-3'.

\section{Statistical analysis}

All data are presented as means \pm S.D. All grouped data were analyzed using SPSS 13.0. Comparisons between groups were made by one-way ANOVA followed by Tukey's test to analyze the differences. Statistical significance was set at $P<0.05$.

\section{Result}

\section{Overexpression of neuritin in hippocampus of mice}

Real-time PCR analysis showed significantly increased mRNA expression of neuritin in the hippocampus of neuritin-overexpressing transgenic C57BL/6J mice compared to the WT mice but not in the cortex (Fig. 1A). Immunochemical staining (Fig. 1B) and Western blotting (Fig. 1C) analysis also confirmed increased neuritin expression. However, neuritin expression was not affected in the other tissues (data not shown). Since there was no difference in the expression of neuritin in the cortex, the subsequent experiments were only focused on the hippocampus.

\section{Effect of neuritin on memory}

Cognitive function was assessed using the Morris water maze test. The mean escape latency for the trained mice decreased from 70 to $17 \mathrm{~s}$ over the course of the 20 learning trials. The mean escape latency did not differ between any of the groups on the first and the second days of testing in the Morris water maze. However, from the third day onwards, there was a significant difference in the transfer latency between $\mathrm{db} / \mathrm{db}$ and $\mathrm{db} / \mathrm{m}$ mice. $\mathrm{db} / \mathrm{db}$ mice showed a lower ability to find the platform and learned its location on the fifth day of training. Neuritin overexpression significantly decreased the mean transfer latency in $\mathrm{db} / \mathrm{db}$ mice (Fig. 2A). This poorer performance was also improved upon treatment with the JAK2 inhibitor, as evident from the animal's decreased latency to find the platform from the third day of training. Figure $2 \mathrm{~B}$ displays the representative swimming paths of mice in the four groups on the fourth day of training. 
A

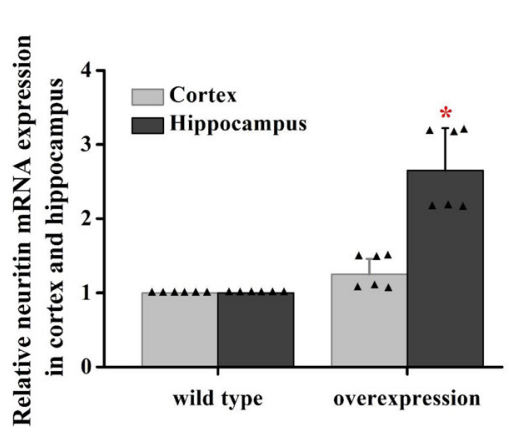

$\mathrm{B}$
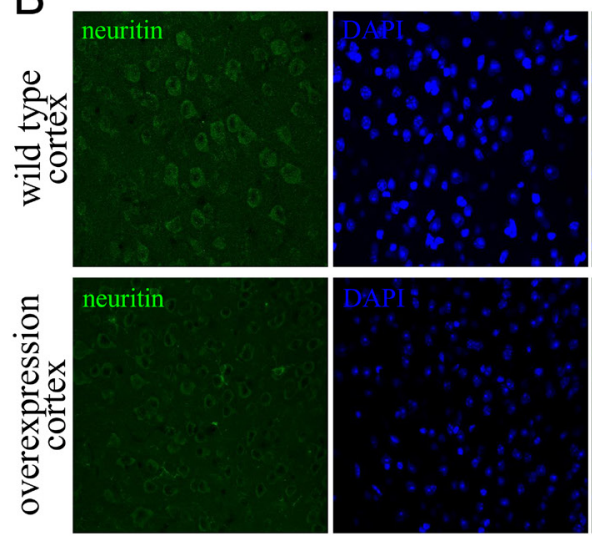

C

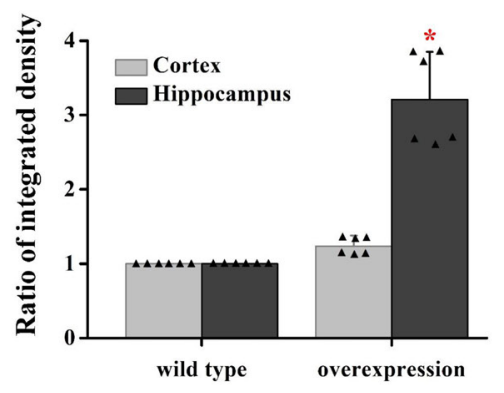

D

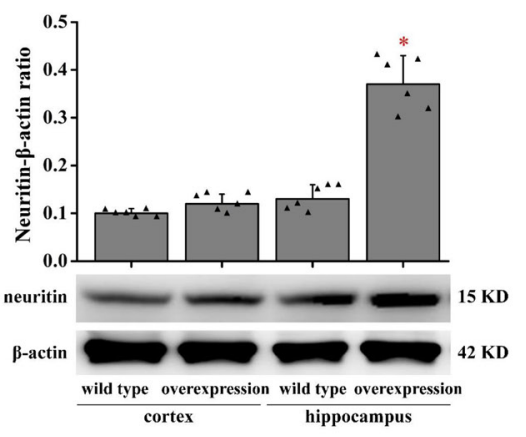

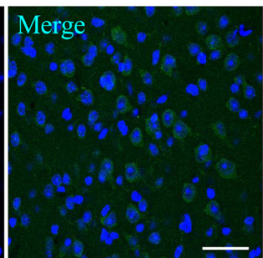
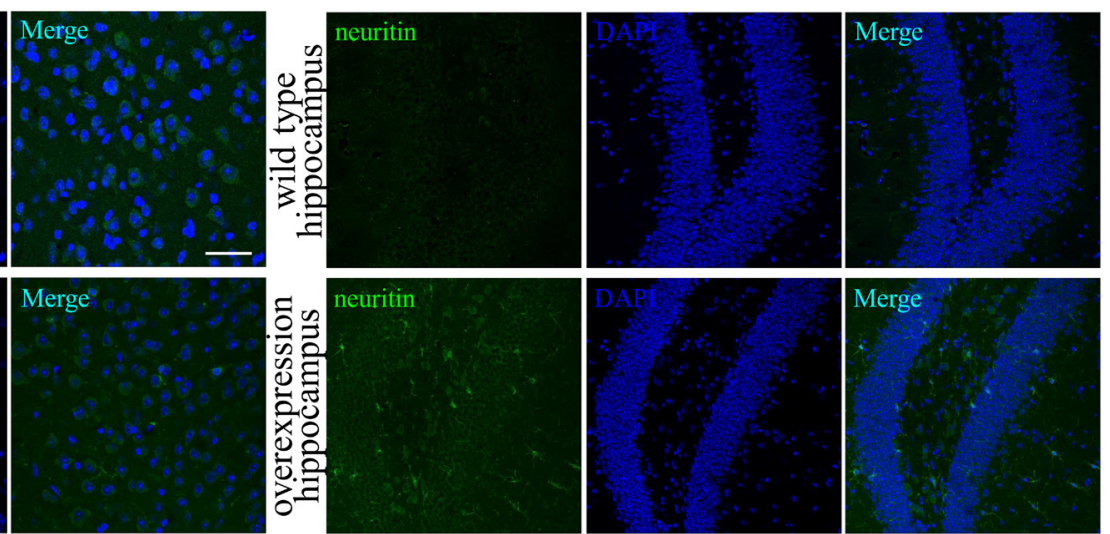

Figure 1

Expression profile of neuritin in the cortex and hippocampus of mice overexpressing neuritin. Neuritin mRNA expression in cortex and hippocampus was measured by real-time PCR in WT and neuritin-overexpressing mice (A). Neuritin expression in the cortex and hippocampus was observed by immunofluorescence (B), the quantification of fluorescence-integrated intensity (C), and by Western blot and its quantification (D) in WT and neuritinoverexpressing mice. Mean \pm standard deviation (s.D.), $n=6 .{ }^{*} p<0.01$, compared with WT mice. Overexpression, neuritin overexpression. A full color version of this figure is available at https://doi.org/10.1530/JOE-20-0321.

Animals showed a significant difference in the probe trial of the Morris water maze study, which measured how well the animals had learned and consolidated the platform location during the 5 days of training (Fig. 2C). $\mathrm{db} / \mathrm{db}$ mice spent less time in the target quadrant than control mice. The time spent in the target quadrant was significantly higher in mice with neuritin overexpression and JAK2 inhibitor-treated $\mathrm{db} / \mathrm{db}$ mice than in $\mathrm{db} / \mathrm{m}$ mice.

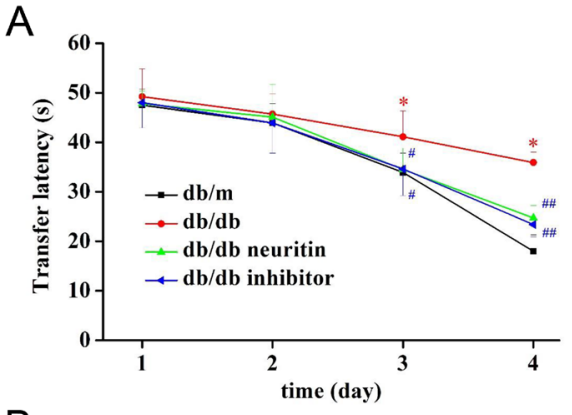

B

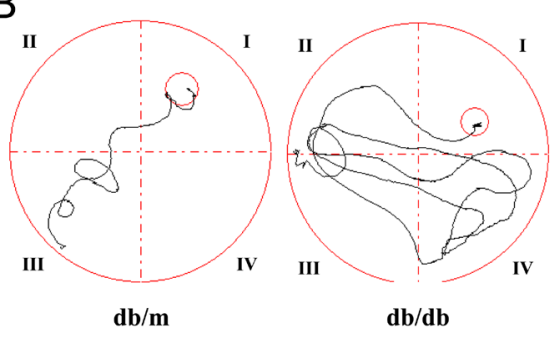

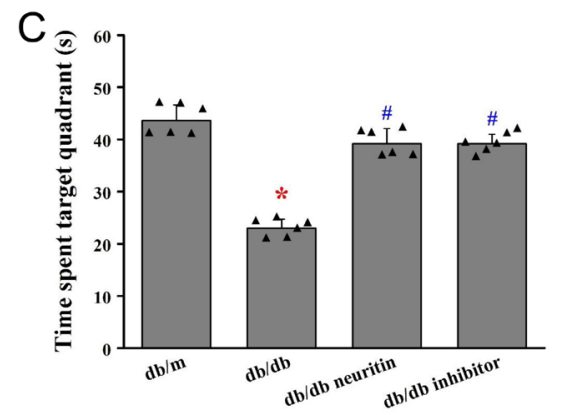

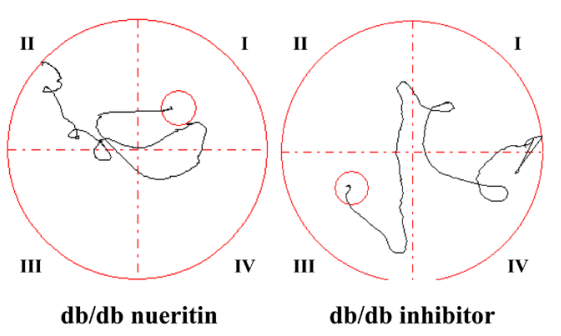

\section{Figure 2}

Effects of neuritin on cognitive dysfunction of $\mathrm{db} / \mathrm{db}$ mice. The alteration of transfer latency (A), pathway maps of searching for the hidden platform at the fourth day of training (B), and the alteration of time spent in the target quadrant (C) during the Morris water maze test. Mean \pm S.D., $n=6 . * P<0.01$, compared with $\mathrm{db} / \mathrm{m}$ mice; $\# P<0.01$, compared with $\mathrm{db} / \mathrm{db}$ mice. $\mathrm{db} / \mathrm{db}$ neuritin, neuritin overexpression $\mathrm{db} / \mathrm{db} ; \mathrm{db} / \mathrm{db}$ inhibitor, db/db JAK2 inhibitor. A full color version of this figure is available at https://doi. org/10.1530/JOE-20-0321. 


\section{Effects of neuritin on body weight and brain weight}

As shown in Fig. $3 \mathrm{~A}, \mathrm{db} / \mathrm{db}$ mice showed significantly higher body weight than $\mathrm{db} / \mathrm{m}$ animals that were fed a standard diet. Neuritin overexpression slightly decreased the body weight of $\mathrm{db} / \mathrm{db}$ mice However, JAK2 inhibitor administration for 8 weeks did not change the body weight of $\mathrm{db} / \mathrm{db}$ mice.

$\mathrm{db} / \mathrm{db}$ mice showed a significant decrease in brain weight compared to $\mathrm{db} / \mathrm{m}$ mice (Fig. 3B). Neuritin overexpression slightly ameliorated the brain weight of $\mathrm{db} / \mathrm{db}$ mice However, JAK2 inhibitor administration for 8 weeks did not affect the brain weight in $\mathrm{db} / \mathrm{db}$ mice.
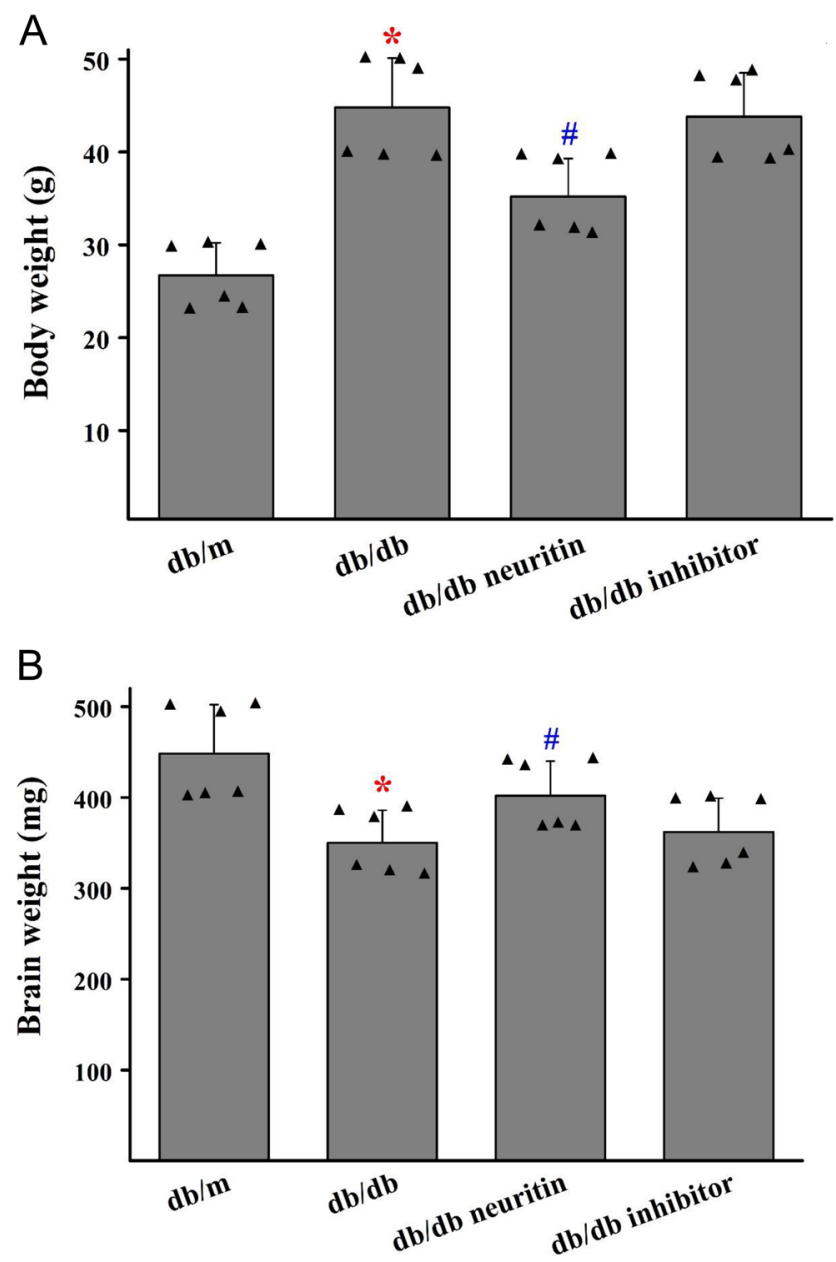

\section{Figure 3}

Effects of neuritin on body weight and brain weight of $\mathrm{db} / \mathrm{db}$ mice. The changes in body weight (A) and brain weight (B). Mean \pm S.D., $n=6$. $\star P<0.01$, compared with $\mathrm{db} / \mathrm{m}$ mice; $\# P<0.05$, compared with $\mathrm{db} / \mathrm{db}$ mice. $\mathrm{db} / \mathrm{db}$ neuritin, neuritin overexpression $\mathrm{db} / \mathrm{db}$; $\mathrm{db} / \mathrm{db}$ inhibitor, $\mathrm{db} / \mathrm{db}$ JAK2 inhibitor. A full color version of this figure is available at https://doi.org/10.1530/JOE-20-0321.

\section{Neuritin improved neuronal impairment in the hippocampus}

Nissl staining revealed a significantly lower number of neurons in $\mathrm{db} / \mathrm{db}$ mice than in $\mathrm{db} / \mathrm{m}$ mice (Fig. $4 \mathrm{~A}$ ). DAPI staining showed a significantly lower number of all cells, including neurons, in $\mathrm{db} / \mathrm{db}$ mice than in $\mathrm{db} / \mathrm{m}$ mice (Fig. 4B). Overexpression of neuritin and JAK2 inhibitor treatment ameliorated these changes in the hippocampus of diabetic mice.

\section{Neuritin ameliorated astrogliosis and synaptic plasticity in hippocampus}

In Fig. 5A, we demonstrated the astrocyte marker GFAP in the hippocampus of each group of mice by immunohistochemistry. There was a significant increase in the expression of GFAP in the hippocampus of $\mathrm{db} / \mathrm{db}$ mice compared to that of standard diet-fed $\mathrm{db} / \mathrm{m}$ mice. GFAP expression was downregulated by both neuritin overexpression and JAK2 inhibitor treatment in $\mathrm{db} / \mathrm{db}$ mice.

$\mathrm{db} / \mathrm{db}$ mice expressed lower levels of synaptophysin in the hippocampus than $\mathrm{db} / \mathrm{m}$ mice (Fig. 5B). Overexpression of neuritin and JAK2 inhibitor treatment upregulated the expression of synaptophysin in the hippocampus of $\mathrm{db} / \mathrm{db}$ mice.

\section{Neuritin regulated JAK2/STAT3 signaling pathway in hippocampus}

To further explore the potential mechanism by which neuritin attenuates hippocampal astrogliosis, we determined the effect of neuritin on the JAK2/STAT3 signaling pathway. Protein expression of p-JAK2 and p-STAT3 was significantly upregulated in $\mathrm{db} / \mathrm{db}$ mice compared to that in $\mathrm{db} / \mathrm{m}$ mice, thereby indicating the activation of the JAK2/STAT3 signaling pathway (Fig. $6 \mathrm{~A}$ and $\mathrm{B})$. This activation was markedly reversed by the overexpression of neuritin and JAK2 inhibitor treatment, as shown by the significantly decreased expression of p-JAK2 and p-STAT3 in $\mathrm{db} / \mathrm{db}$ mice. This provided compelling evidence that the neuritin interfered with the JAK2/STAT3 signaling pathway in the hippocampus.

\section{Neuritin inhibited lipopolysaccharide-induced gliosis in U-118MG cells}

Lipopolysaccharide significantly upregulated GFAP expression in U-118G cells compared to that in the control group (Fig. 7). However, when pretreated with recombinant

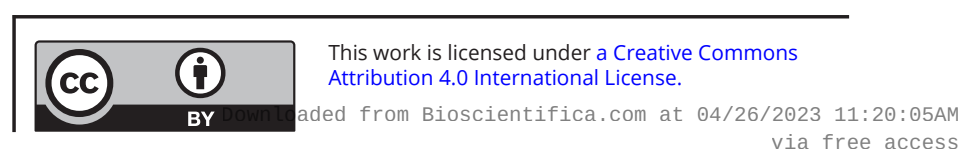


A

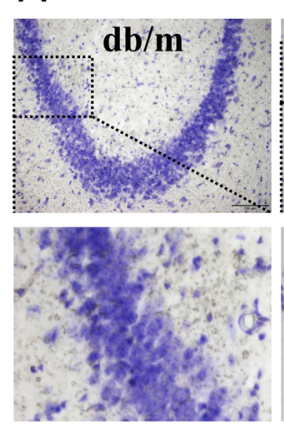

C
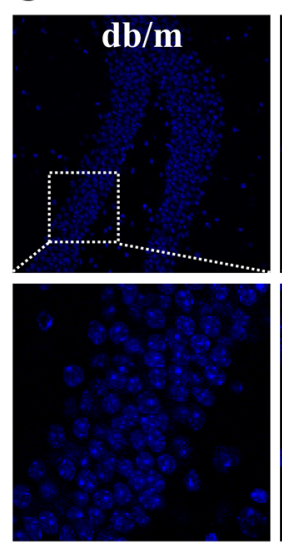
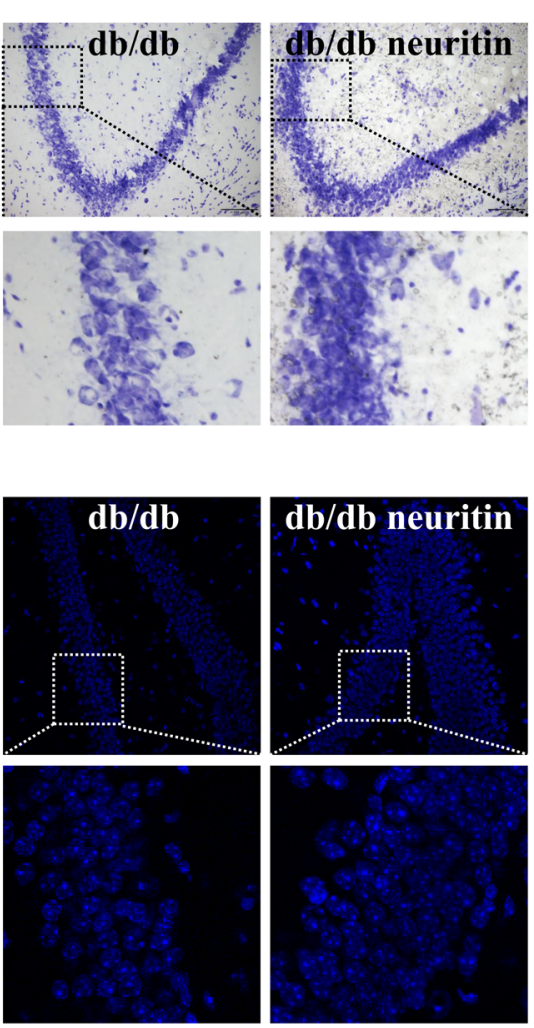

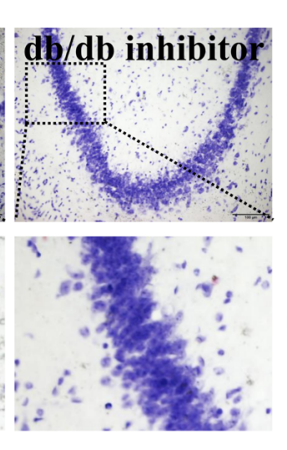

B

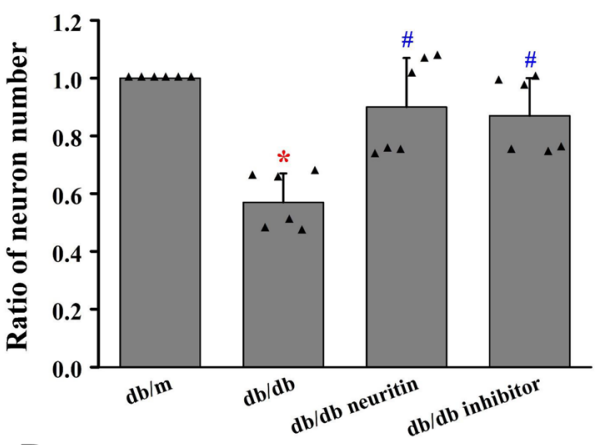

$\mathrm{D}$
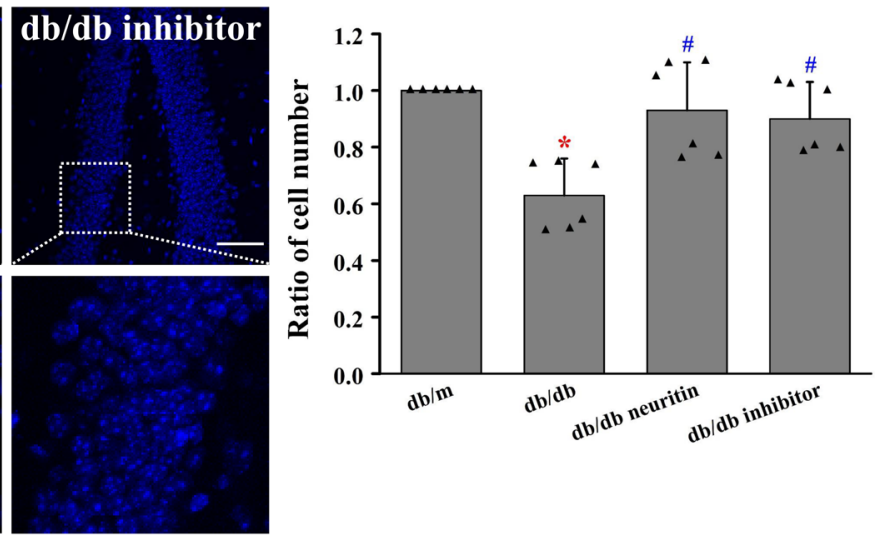

Figure 4

Neuritin ameliorated neuronal impairment in hippocampus. The Nissl staining (A) and its quantification analysis (B) and DAPI staining (C) and its quantification analysis (D) in the hippocampus. Mean \pm S.D., $n=6$. $* P<0.01$, compared with $\mathrm{db} / \mathrm{m}$ mice; $\# P<0.01$, compared with $\mathrm{db} / \mathrm{db}$ mice. Scale bar $=100 \mu \mathrm{m}$ in $\mathrm{A}$, scale bar $=50 \mu \mathrm{m}$ in $\mathrm{B}$. $\mathrm{db} / \mathrm{db}$ neuritin, neuritin overexpression $\mathrm{db} / \mathrm{db}$; db/db inhibitor, $\mathrm{db} / \mathrm{db}$ JAK2 inhibitor. A full color version of this figure is available at https://doi.org/10.1530/JOE-20-0321.

neuritin (100 ng/mL), JAK2 inhibitor, or STAT3 inhibitor for $30 \mathrm{~min}$, there was a suppressed GFAP expression.

\section{Neuritin suppressed lipopolysaccharide-stimulated JAK2/STAT3 pathway activation in U-118MG cells}

Lipopolysaccharide significantly increased the phosphorylation of JAK2 and STAT3 in U-118MG cells without affecting the total levels of the proteins. However, $30 \mathrm{~min}$ pretreatment with recombinant neuritin $(100 \mathrm{ng} / \mathrm{mL})$ decreased the phosphorylation of JAK2 and STAT3, while the phosphorylation of JAK2 and STAT3 showed a similar trend when the cells were incubated with JAK2 inhibitor. However, the STAT3 inhibitor only downregulated the expression of p-STAT3 (Fig. 8).

\section{Discussion}

Our study found that neuritin overexpression in the hippocampus of $\mathrm{db} / \mathrm{db}$ mice significantly ameliorated (c) 2021 The authors cognitive dysfunction, neuronal impairment, and synaptic plasticity, and inhibited astrogliosis and the JAK2/STAT3 signaling pathway in the hippocampus. Neuritin also suppressed the JAK2/STAT3 signaling pathway to inhibit lipopolysaccharide-induced gliosis in U-118MG cells.

Obesity is the single best predictor of whether a person would develop type 2 diabetes. In our study, $\mathrm{db} / \mathrm{db}$ mice were fed a high-fat diet to induce diabetic neuropathy (Islam 2013). Our results show that there is significant downregulation in the expression of neuritin and increased body weight in $\mathrm{db} / \mathrm{db}$ mice compared to control mice. The downregulated expression of neuritin might, thus, be body weight dependent, which is in accordance with the results of previous investigations in streptozotocin-induced diabetic rats (Karamoysoyli et al. 2008, Xi et al. 2020). There are no reports on the side effects of acute and chronic exogenous neuritin administration in mice or rats (An et al. 2014, Gao et al. 2016, Xi et al. 2020).

The diabetic brain has structural and functional abnormalities, including atrophy of the whole brain, 
A
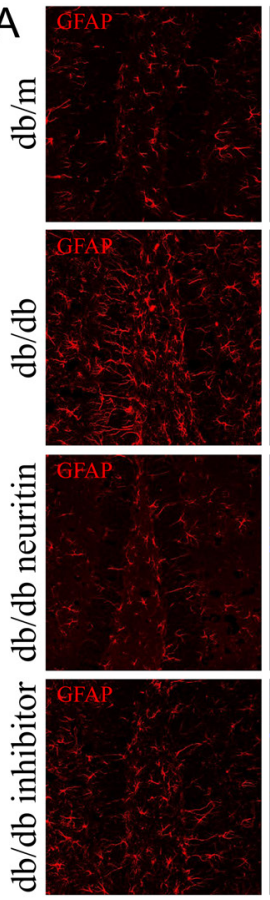

B
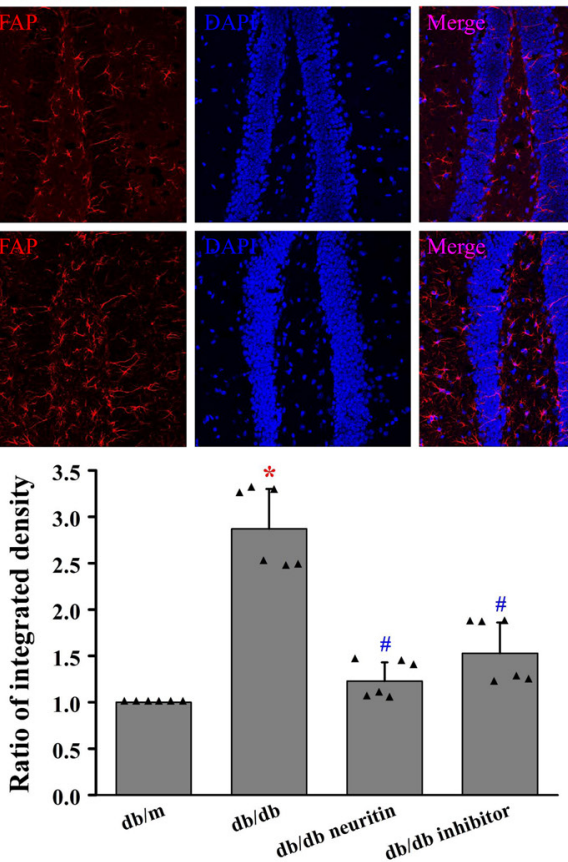
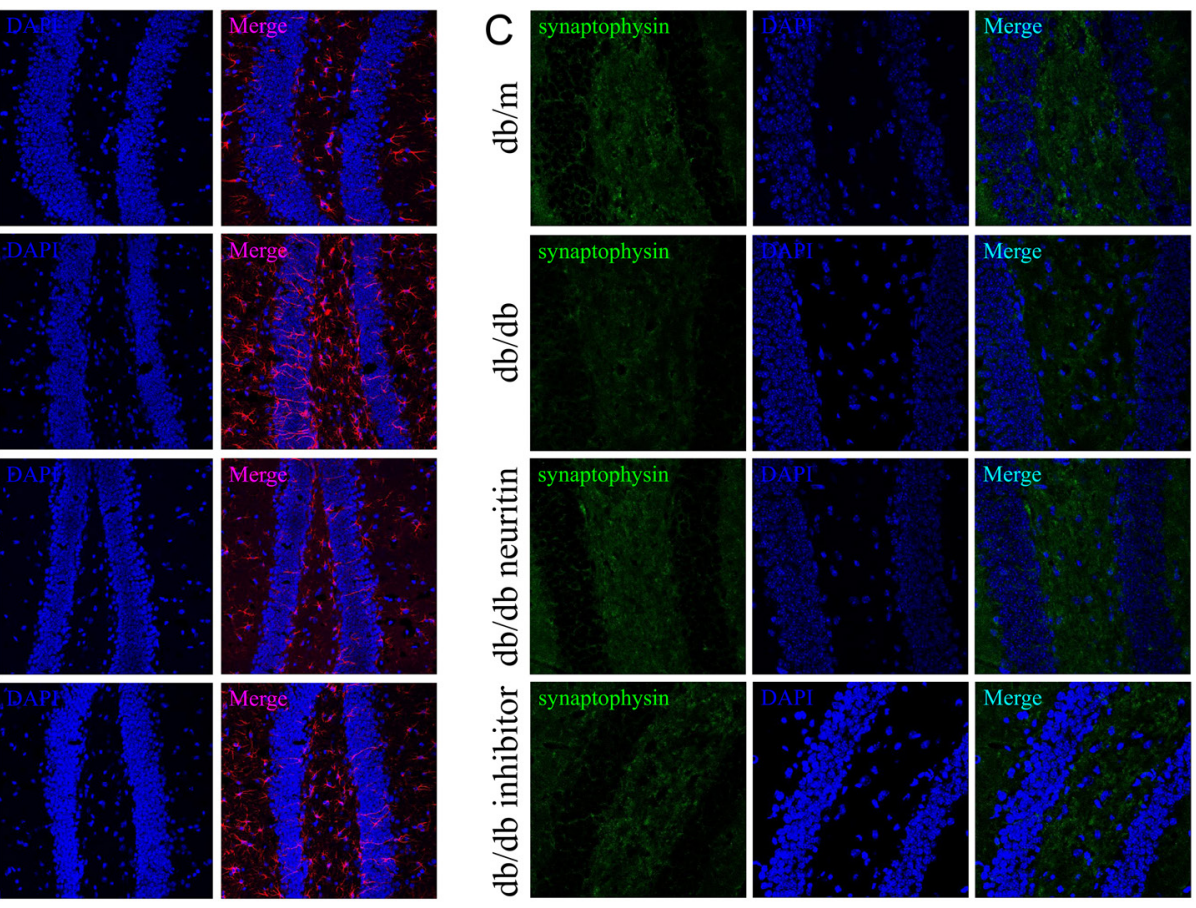

D

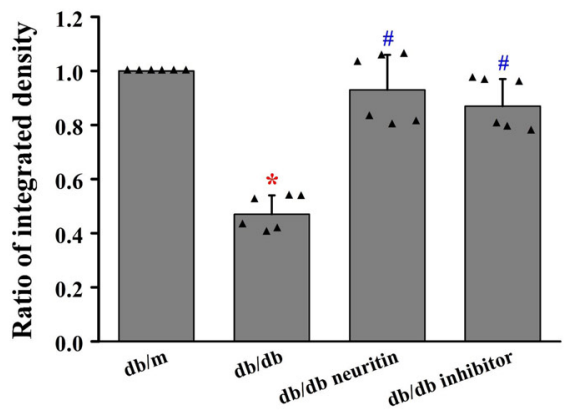

\section{Figure 5}

Neuritin ameliorated astrogliosis and synaptic plasticity in the hippocampus. GFAP protein was measured using immunofluorescence in the hippocampus (A) and its quantification of fluorescence integrated intensity (B). Synaptophysin protein was measured using immunofluorescence (C) and its quantification of fluorescence integrated intensity (D). Mean \pm s.D., $n=6$. ${ }^{*} P<0.01$, compared with $\mathrm{db} / \mathrm{m} \mathrm{mice;}{ }^{*}<<0.01$, compared with $\mathrm{db} / \mathrm{db}$ mice. $\mathrm{db} / \mathrm{db}$ neuritin, neuritin overexpression $\mathrm{db} / \mathrm{db}$; $\mathrm{db} / \mathrm{db}$ inhibitor, $\mathrm{db} / \mathrm{db}$ JAK2 inhibitor. A full color version of this figure is available at https://doi. org/10.1530/JOE-20-0321

gray matter, hippocampus, and amygdala. Progressive brain atrophy (Zhou et al. 2020), axon loss, and neuronal degeneration in the cortex and hippocampus have been observed in diabetic animals and humans (Klein \& Waxman 2003). Consistent with previous reports in $\mathrm{db} / \mathrm{db}$ mice showing that the brains of $\mathrm{db} / \mathrm{db}$ mice are smaller and lighter than those of control mice (Sheppard et al. 1985, Makar et al. 1995, Vannucci et al. 1997, Ahima et al. 1999), our results showed that the brain weight of $\mathrm{db} / \mathrm{db}$ mice was remarkably lower than that of $\mathrm{db} / \mathrm{m}$ mice. According to the Jackson Laboratory, recombination (overexpression of neuritin) occurs in approximately $88 \%$ neurons of the neocortex and hippocampus, and in the glia of the cerebral cortex. Cortical excitatory neurons and glia (radial glia, astrocytes, and oligodendrocytes), but not GABAergic neurons, are produced in the Emx1-expressing lineage (Gorski et al. 2002). Overexpression of neuritin in the cortex and hippocampus increases the lower brain weight of $\mathrm{db} / \mathrm{db}$ mice, but JAK2 inhibitor has no effect on the brain weight of $\mathrm{db} / \mathrm{db}$ mice. Consistent with previous reports following Nissl and DAPI staining (Yan et al. 2009, Zhang et al. 2018), db/db mice showed a lower number of neurons and all cells in the hippocampus than that in $\mathrm{db} / \mathrm{m}$ mice. Overexpression of neuritin prevents the loss of neurons in $\mathrm{db} / \mathrm{db}$ mice, but JAK2 inhibitors could not restore the lost neurons in $\mathrm{db} / \mathrm{db}$ mice. Global knockout of neuritin in mice accelerates retinal ganglion cell loss and retinal degeneration following optic nerve https://jme.bioscientifica.com https://doi.org/10.1530/JME-20-0321 (c) 2021 The authors Published by Bioscientifica Ltd. Printed in Great Britain

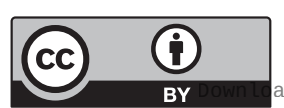

This work is licensed under a Creative Commons Attribution 4.0 International License. ded from Bioscientifica.com at 04/26/2023 11:20:05AM 

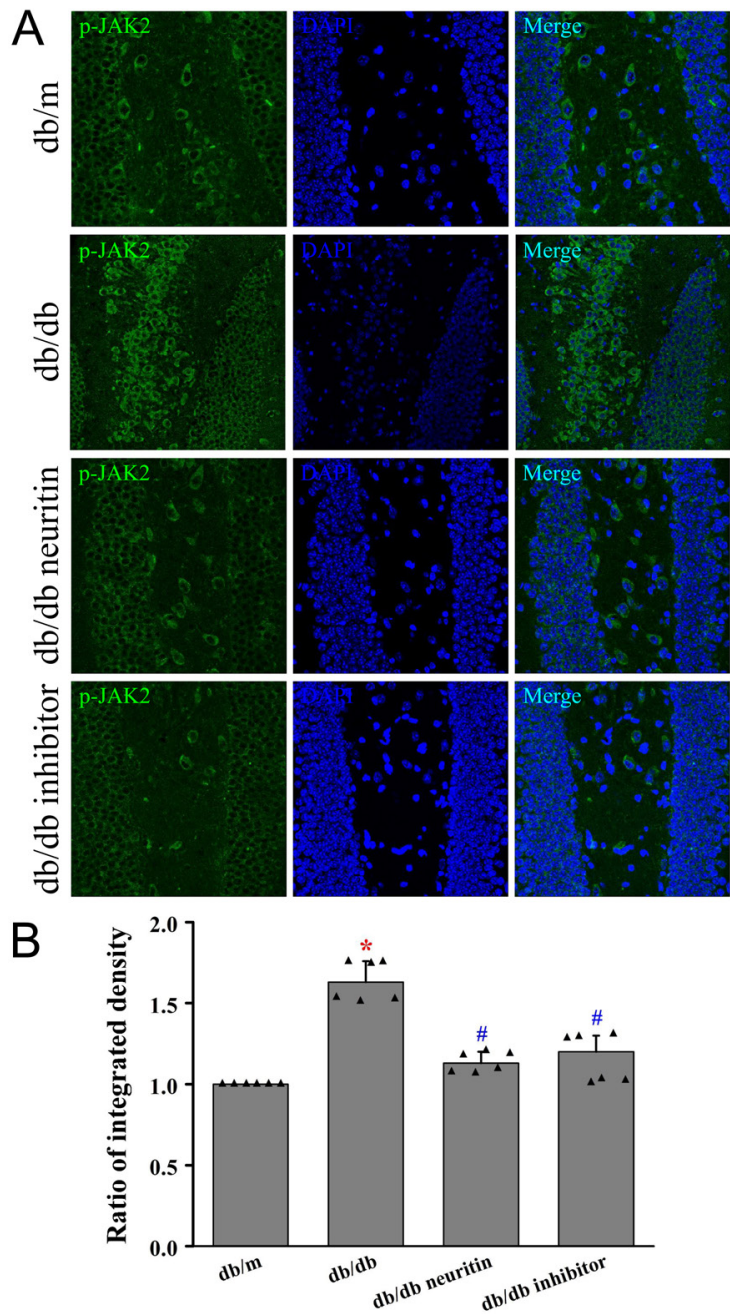
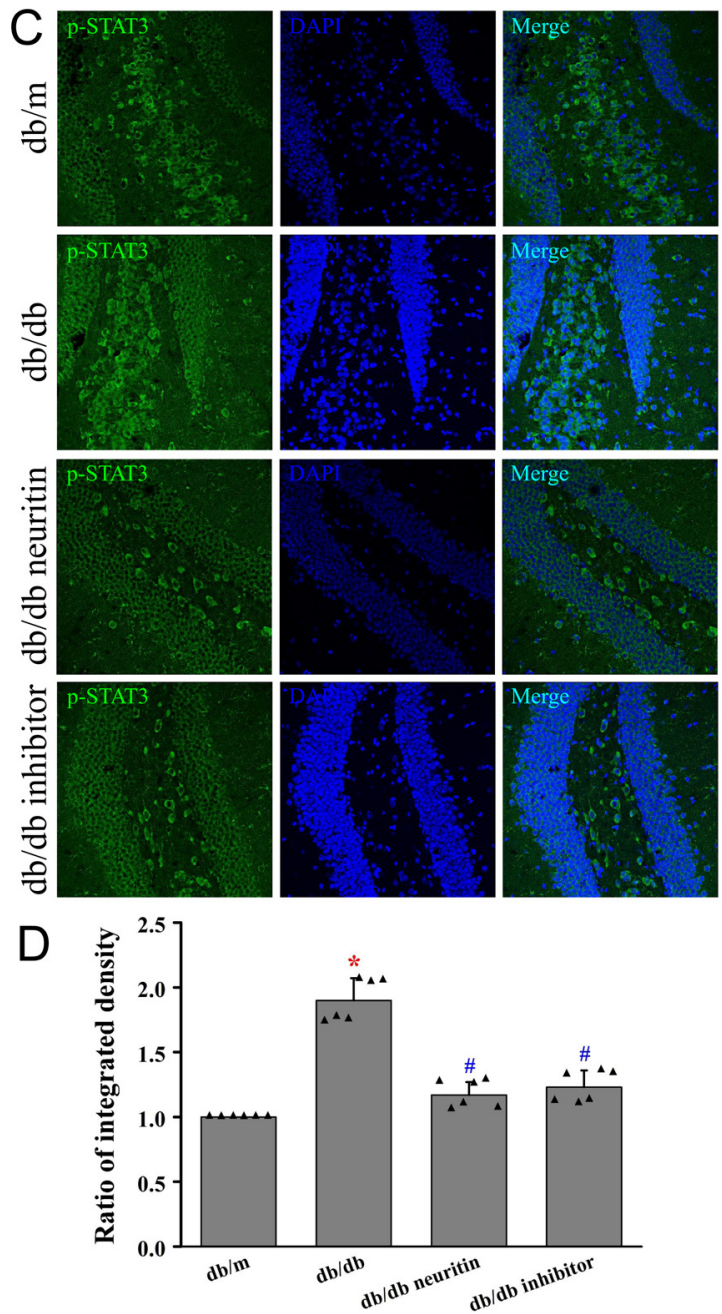

\section{Figure 6}

Neuritin suppressed JAK2/STAT3 signaling pathway in the hippocampus. Phosphorylation level of JAK2 was measured using immunofluorescence in hippocampus (A) and its quantification of fluorescence integrated intensity (B). Phosphorylation level of STAT3 was measured using immunofluorescence (C) and its quantification of fluorescence integrated intensity (D). Mean \pm s.D., $n=6$. * $P<0.01$, compared with $\mathrm{db} / \mathrm{m} \mathrm{mice}$; ${ }^{2} P<0.01$, compared with $\mathrm{db} / \mathrm{db}$ mice. $\mathrm{db} / \mathrm{db}$ neuritin, neuritin overexpression $\mathrm{db} / \mathrm{db}$; db/db inhibitor, $\mathrm{db} / \mathrm{db}$ JAK2 inhibitor. A full color version of this figure is available at https://doi. org/10.1530/JOE-20-0321.

injury (Azuchi et al. 2018), while adeno-associated virus-mediated overexpression of neuritin delays retinal ganglion cell apoptosis, regenerates injured axons, and maintains retinal ganglion cell function following optic nerve injury (Sharma et al. 2015). Neuritin has similar protective effects against sciatic nerve injury in rats (Wang et al. 2016).

Diabetic central neuropathy is a critical complication of diabetes and is characterized by cognitive dysfunction and neurochemical and structural impairments (Sima 2010). Patients with type 2 diabetes have a higher risk of cognitive dysfunction, with deficits in short-term memory and executive function. Older type 2 diabetic patients have several impaired cognitive domains, with the highest ratio of impaired psychomotor speed (McCrimmon et al. 2012). In accordance with other reports (Infante-Garcia et al. 2017, Yan et al. 2019, Yermakov et al. 2019), in the Morris water maze test, diabetic mice showed exacerbated cognitive performance. Overexpression of neuritin ameliorated cognitive impairment, and the JAK2 inhibitor showed the same effects in diabetic mice.

Regional brain injury is tightly associated with neurocognitive impairment, especially in the hippocampus, which is mainly responsible for learning and memory (Stranahan et al. 2008). Synaptic plasticity is important for function of the neurons as plastic alterations in synaptic strength seem to be implicated in learning and memory (Bliss \& Collingridge 1993). https://jme.bioscientifica.com https://doi.org/10.1530/JME-20-0321 (c) 2021 The authors Published by Bioscientifica Ltd. Printed in Great Britain

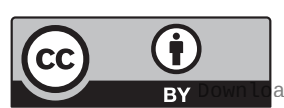

This work is licensed under a Creative Commons Attribution 4.0 International License. ded from Bioscientifica.com at 04/26/2023 11:20:05AM 


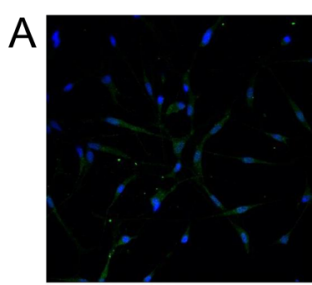

Control
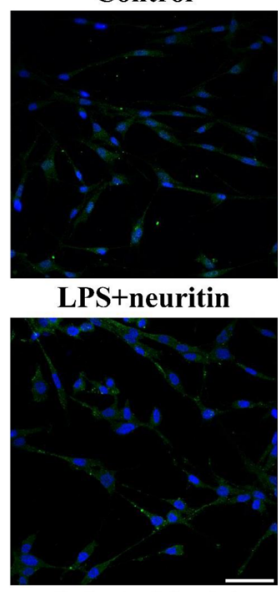

LPS+STAT3 inhibitor

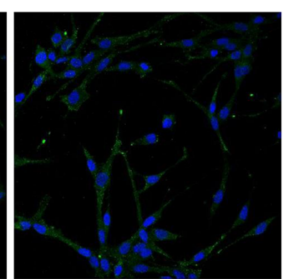

LPS

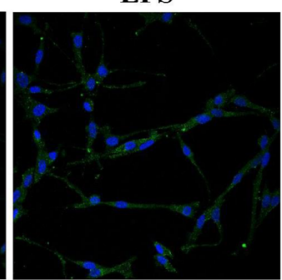

LPS +JAK2 inhibitor
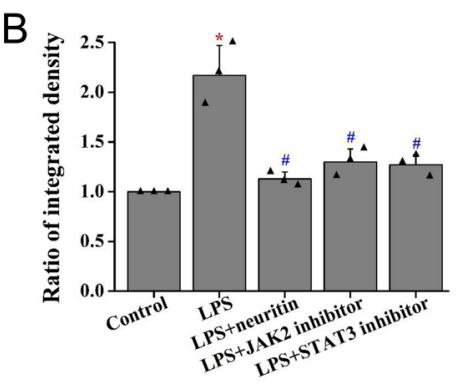

C
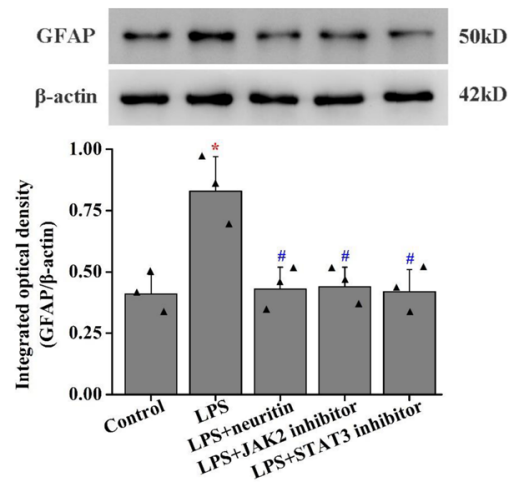

\section{Figure 7}

Neuritin inhibited gliosis in U-118MG cells. GFAP protein was measured using immunofluorescence in $U-118 M G$ cells (A) and its quantification of fluorescence-integrated intensity (B). GFAP protein was measured using Western blot and its quantification (C). Data are given as mean \pm S.D. $(n=3) .{ }^{*} P<0.01$ vs control cells; $\# P<0.01$ vs lipopolysaccharide-induced cells. LPS, lipopolysaccharide. A full color version of this figure is available at https://doi.org/10.1530/ JOE-20-0321.

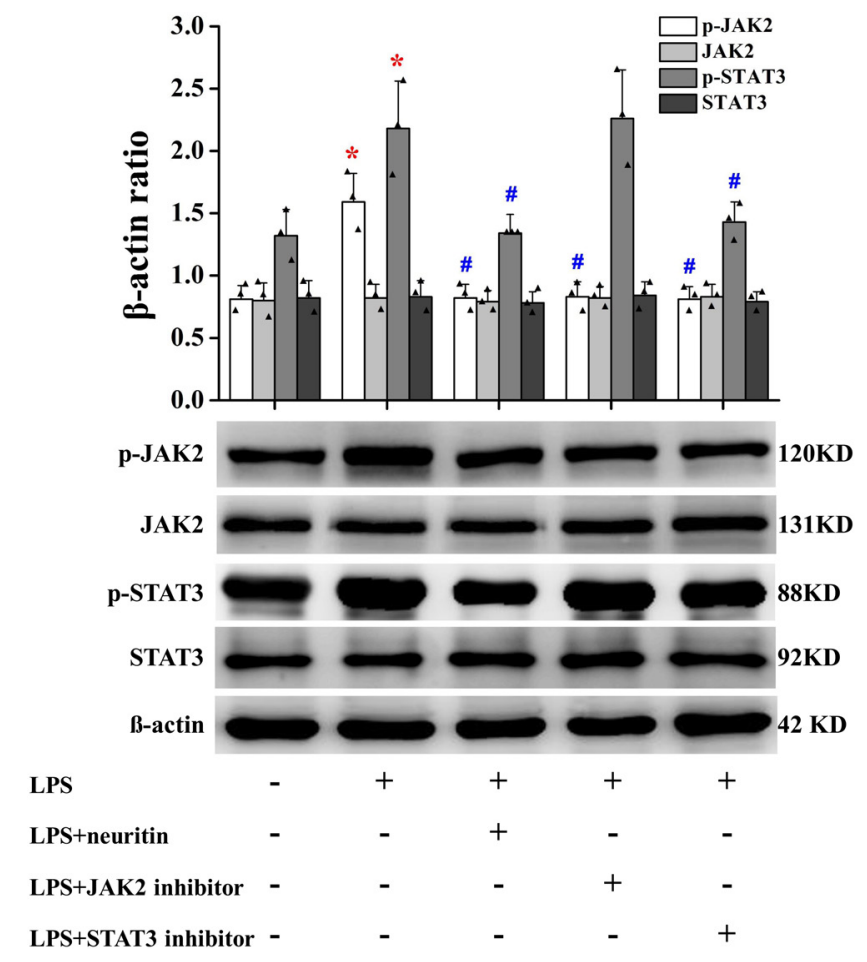

Figure 8

Neuritin inhibits JAK2/STAT3 signaling pathway in U-118MG cells. Data are given as mean \pm S.D. $(n=3)$. ${ }^{*} P<0.01$ vs control cells; $\# P<0.01$ vs lipopolysaccharide-induced cells. LPS, lipopolysaccharide. A full color version of this figure is available at https://doi.org/10.1530/JOE-20-0321.
Synaptophysin is ubiquitous at the synapse, and therefore, synaptophysin immunostaining could be used for the quantification of synapses (Calhoun et al. 1996). Consistent with previous reports that diabetic mice show lower expression of synaptophysin in the hippocampus than control mice (Li et al. 2012, King et al. 2013, Porter et al. 2013), our results show that $\mathrm{db} / \mathrm{db}$ mice expressed lower levels of synaptophysin in the hippocampus than $\mathrm{db} / \mathrm{m}$ mice. Overexpression of neuritin and JAK2 inhibitor treatment upregulated the expression of synaptophysin in the hippocampus of $\mathrm{db} / \mathrm{db}$ mice. Neuritin causes synapse formation and plasticity, neuritogenesis, neurite outgrowth, and neurite arborization, which participate in the development and function of the CNS (Putz et al. 2005, Fujino et al. 2011, Shimada et al. 2016, Subramanian et al. 2019).

Reactive astrocytes are essential in acute tissue remodeling and wound healing processes, eventually changing to scar-forming astrocytes and to become a dense glial scar (Okada et al. 2018). GFAP is strongly expressed in both reactive and scar-forming astrocytes. In several neurological diseases, reactive astrogliosis is a response to activated astrocytes. In most conditions, reactive astrogliosis can be considered a defensive reaction to resist acute stress, reversing CNS homeostasis, and preventing tissue damage. Continuing reactive astrogliosis can be maladaptive, resulting in the suppression of neural plasticity and regenerative responses (Pekny \& Pekna 2014).

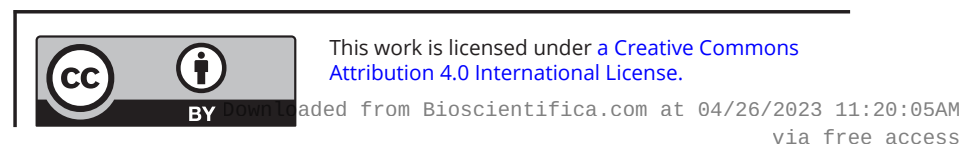


Astrocytes are active participants in synaptic processing and are involved in local synaptic plasticity. Astrocytes actively participate in normal memory function and abnormal processes, resulting in cognitive dysfunction under pathological conditions (Santello et al. 2019). Astrocytes regulate neuronal excitability, synaptic plasticity, and activity, and play a critical role in cognitive functions, such as learning and memory. Astrocyte regulation is considered as the focal point of processing cellular substrates for information and memory formation (Dallerac \& Rouach 2016). Gliosis induced by astrocyte activation causes hippocampal neuronal impairment, leading to cognitive impairment (Shentu et al. 2019). Our results show that $\mathrm{db} / \mathrm{db}$ mice have higher astrogliosis in the hippocampus than $\mathrm{db} / \mathrm{m}$ mice. Neuritin overexpression ameliorates astrogliosis in $\mathrm{db} / \mathrm{db}$ mice. Astrocyte degeneration, reactive astrogliosis and dystrophy are observed in Alzheimer's disease (Shentu et al. 2019). In addition, astrocyte loss occurs at later stages of some neurodegenerative diseases, which might indirectly change neuronal function and survival (Rossi et al. 2008, Rodriguez et al. 2009, Martorana et al. 2012). However, another study showed that glial scar tissue formed after spinal cord injury might support neuron regeneration (Anderson et al. 2016).

Neuritin is an extracellular, glycosylphosphoinositidelinked protein that can be secreted in a soluble form by various cells, including neurons and astrocytes (Naeve et al. 1997, Putz et al. 2005, Zhao et al. 2017). One recent study found that the soluble form of neuritin from astrocytes repairs the damaged hippocampal neurons caused by ischemia by adhering to the neuronal surface. The increased expression of neuritin in astrocytes stimulated by ischemia might be triggered by modulation of cAMP response element-binding protein phosphorylation, mitogen-activated protein kinases, and phosphatidylinositide 3-kinases signaling pathways (Zhao et al. 2017).

Our results showed that the overexpression of neuritin suppressed the activated JAK2/STAT3 signaling pathway in the hippocampus of $\mathrm{db} / \mathrm{db}$ mice and neuritin suppressed JAK2/STAT3 signaling pathway to inhibit lipopolysaccharide-induced gliosis in U-118MG cells. Other studies have shown that astrogliosis has the potential to interfere with synapse sprouting (Cirillo et al. 2012, Shentu et al. 2019) and is associated with the JAK2/STAT3 signaling pathway (Robson et al. 2014). Astrogliosis might also damage neuronal survival, which is ameliorated by JAK2 inhibition (Ignarro et al. 2013). LPS induces the activation of retinal astrocytes via the Printed in Great Britain
JAK2/STAT3 signaling pathway (Jang et al. 2007). The JAK2/STAT3 signaling pathway also contributes to the development of diabetic macrovascular complications by mediating inflammation associated with vascular endothelial cells and/or monocytes (Yang et al. 2017) and involves the renal protective effect of paeoniflorin (Li et al. 2018).

In conclusion, neuritin overexpression in the hippocampus of $\mathrm{db} / \mathrm{db}$ mice significantly ameliorated cognitive dysfunction, hippocampal neuronal impairment, and synaptic plasticity deterioration, and suppressed astrogliosis and the JAK2/STAT3 signaling pathway in the hippocampus. Neuritin regulates the JAK2/STAT3 signaling pathway to inhibit lipopolysaccharide-induced gliosis in U-118MG cells. Therefore, neuritin might at least partly regulate the JAK2/STAT3 signaling pathway to inhibit astrogliosis and improve diabetic cognitive dysfunction.

\section{Declaration of interest}

The authors declare that there is no conflict of interest that could be perceived as prejudicing the impartiality of the research reported.

\section{Funding}

This study is supported by grants from the National Natural Science Foundation of China (Nos. 81770806), the Chongqing Natural Science Foundation of China (No. CSTC2016shmszx130006), and Special Project for Enhancing Science and Technology Innovation Ability of Army Military Medical University (No. 2019XYY16).

\section{Author contribution statement}

$\mathrm{J} Z$ designed the experiments; $Z \mathrm{Z}$ and $\mathrm{H} Z$ performed the experiments; $Z \mathrm{Z}$ and $\mathrm{H} \mathrm{Z}$ analyzed the data; $\mathrm{Z} \mathrm{Z,} \mathrm{H} \mathrm{Z} \mathrm{and} \mathrm{J} \mathrm{Z} \mathrm{wrote} \mathrm{the} \mathrm{manuscript;} \mathrm{Z} \mathrm{Z,} \mathrm{H} \mathrm{Z}$ and $\mathrm{J} Z$ edited the manuscript; $Z \mathrm{Z}, \mathrm{H} Z$ and $\mathrm{J} Z$ read and approved the final manuscript.

\section{References}

Ahima RS, Bjorbaek C, Osei S \& Flier JS 1999 Regulation of neuronal and glial proteins by leptin: implications for brain development. Endocrinology 140 2755-2762. (https://doi.org/10.1210/ endo.140.6.6774)

An K, Jung JH, Jeong AY, Kim HG, Jung SY, Lee K, Kim HJ, Kim SJ, Jeong TY, Son Y, et al. 2014 Neuritin can normalize neural deficits of Alzheimer's disease. Cell Death and Disease 5 e1523. (https://doi. org/10.1038/cddis.2014.478)

Anderson MA, Burda JE, Ren Y, Ao Y, O'Shea TM, Kawaguchi R, Coppola G, Khakh BS, Deming TJ \& Sofroniew MV 2016 Astrocyte scar formation aids central nervous system axon regeneration. Nature 532 195-200. (https://doi.org/10.1038/nature17623)

Areosa Sastre A, Vernooij RW, González-Colaço Harmand M \& Martínez G 2017 Effect of the treatment of Type 2 diabetes mellitus

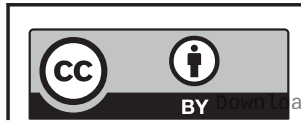

This work is licensed under a Creative Commons Attribution 4.0 International License. ded from Bioscientifica.com at 04/26/2023 11:20:05AM 
on the development of cognitive impairment and dementia. Cochrane Database of Systematic Reviews 6 CD003804. (https://doi. org/10.1002/14651858.CD003804.pub2)

Azuchi Y, Namekata K, Shimada T, Guo X, Kimura A, Harada C, Saito A, Yamagata K \& Harada T 2018 Role of neuritin in retinal ganglion cell death in adult mice following optic nerve injury. Scientific Reports 8 10132. (https://doi.org/10.1038/s41598-01828425-7)

Bliss TVP \& Collingridge GL 1993 A synaptic model of memory: longterm potentiation in the hippocampus. Nature 361 31-39. (https:// doi.org/10.1038/361031a0)

Calhoun ME, Jucker M, Martin LJ, Thinakaran G, Price DL \& Mouton PR 1996 Comparative evaluation of synaptophysin-based methods for quantification of synapses. Journal of Neurocytology 25 821-828. (https://doi.org/10.1007/BF02284844)

Ceyzeriat K, Abjean L, Carrillo-de Sauvage MA, Ben Haim L \& Escartin C 2016 The complex STATes of astrocyte reactivity: how are they controlled by the JAK-STAT3 pathway? Neuroscience 330 205-218. (https://doi.org/10.1016/j.neuroscience.2016.05.043)

Ceyzeriat K, Ben Haim L, Denizot A, Pommier D, Matos M, Guillemaud O, Palomares MA, Abjean L, Petit F, Gipchtein P, et al. 2018 Modulation of astrocyte reactivity improves functional deficits in mouse models of Alzheimer's disease. Acta Neuropathologica Communications 6 104. (https://doi.org/10.1186/s40478-018-0606-1)

Chen X, Nie X, Mao J, Zhang Y, Yin K \& Jiang S 2018 Perfluorooctanesulfonate induces neuroinflammation through the secretion of TNF-alpha mediated by the JAK2/STAT3 pathway. Neurotoxicology 66 32-42. (https://doi.org/10.1016/j. neuro.2018.03.003)

Cirillo G, Colangelo AM, Bianco MR, Cavaliere C, Zaccaro L, Sarmientos P, Alberghina L \& Papa M 2012 BB14, a nerve growth factor (NGF)-like peptide shown to be effective in reducing reactive astrogliosis and restoring synaptic homeostasis in a rat model of peripheral nerve injury. Biotechnology Advances 30 223-232. (https:// doi.org/10.1016/j.biotechadv.2011.05.008)

Dallerac G \& Rouach N 2016 Astrocytes as new targets to improve cognitive functions. Progress in Neurobiology 144 48-67. (https://doi. org/10.1016/j.pneurobio.2016.01.003)

Duarte JM, Agostinho PM, Carvalho RA \& Cunha RA 2012 Caffeine consumption prevents diabetes-induced memory impairment and synaptotoxicity in the hippocampus of NONcZNO10/LTJ mice. PLoS ONE 7 e21899. (https://doi.org/10.1371/journal.pone.0021899)

Fujino T, Leslie JH, Eavri R, Chen JL, Lin WC, Flanders GH, Borok E, Horvath TL \& Nedivi E 2011 CPG15 regulates synapse stability in the developing and adult brain. Genes and Development $\mathbf{2 5}$ 2674-2685. (https://doi.org/10.1101/gad.176172.111)

Gao H, Wu D, Zhang E, Liang T, Meng X, Chen L \& Wu Y 2019 Phasic change and apoptosis regulation of JAK2/STAT3 pathway in a type 2 diabetic rat model. American Journal of Translational Research $\mathbf{1 1}$ 911-930.

Gao R, Li X, Xi S, Wang H, Zhang H, Zhu J, Shan L, Song X, Luo X, Yang L, et al. 2016 Exogenous neuritin promotes nerve regeneration after acute spinal cord injury in rats. Human Gene Therapy $\mathbf{2 7}$ 544-554. (https://doi.org/10.1089/hum.2015.159)

Gorski JA, Talley T, Qiu M, Puelles L, Rubenstein JL \& Jones KR 2002 Cortical excitatory neurons and glia, but not GABAergic neurons, are produced in the Emx1-expressing lineage. Journal of Neuroscience 22 6309-6314. (https://doi.org/10.1523/JNEUROSCI.22-15-06309.2002)

Gurzov EN, Stanley WJ, Pappas EG, Thomas HE \& Gough DJ 2016 The JAK/STAT pathway in obesity and diabetes. FEBS Journal $\mathbf{2 8 3}$ 3002-3015. (https://doi.org/10.1111/febs.13709)

Huang RR, Jia BH, Xie L, Ma SH, Yin JJ, Sun ZB, Le HB, Xu WC, Huang JZ \& Luo DX 2016 Spatial working memory impairment in primary onset middle-age type 2 diabetes mellitus: an ethology and BOLD-fMRI study. Journal of Magnetic Resonance Imaging 43 75-87. (https://doi.org/10.1002/jmri.24967) Printed in Great Britain
Ignarro RS, Vieira AS, Sartori CR, Langone F, Rogerio F \& Parada CA 2013 JAK2 inhibition is neuroprotective and reduces astrogliosis after quinolinic acid striatal lesion in adult mice. Journal of Chemical Neuroanatomy 48-49 14-22. (https://doi.org/10.1016/j. jchemneu.2013.02.005)

Infante-Garcia C, Jose Ramos-Rodriguez J, Marin-Zambrana Y, Teresa Fernandez-Ponce M, Casas L, Mantell C \& Garcia-Alloza M 2017 Mango leaf extract improves central pathology and cognitive impairment in a type 2 diabetes mouse model. Brain Pathology $\mathbf{2 7}$ 499-507. (https://doi.org/10.1111/bpa.12433)

Islam MS 2013 Animal models of diabetic neuropathy: progress since 1960s. Journal of Diabetes Research 2013 149452. (https://doi. org/10.1155/2013/149452)

Jang S, Lee JH, Choi KR, Kim D, Yoo HS \& Oh S 2007 Cytochemical alterations in the rat retina by LPS administration. Neurochemical Research 32 1-10. (https://doi.org/10.1007/s11064-006-9215-7)

Karamoysoyli E, Burnand RC, Tomlinson DR \& Gardiner NJ 2008 Neuritin mediates nerve growth factor-induced axonal regeneration and is deficient in experimental diabetic neuropathy. Diabetes $\mathbf{5 7}$ 181-189. (https://doi.org/10.2337/db07-0895)

King MR, Anderson NJ, Guernsey LS \& Jolivalt CG 2013 Glycogen synthase kinase-3 inhibition prevents learning deficits in diabetic mice. Journal of Neuroscience Research 91 506-514. (https://doi. org/10.1002/jnr.23192)

Klein JP \& Waxman SG 2003 The brain in diabetes: molecular changes in neurons and their implications for end-organ damage. Lancet. Neurology 2 548-554. (https://doi.org/10.1016/s1474-4422(03)00503-9)

Koyama Y 2014 Signaling molecules regulating phenotypic conversions of astrocytes and glial scar formation in damaged nerve tissues. Neurochemistry International 78 35-42. (https://doi.org/10.1016/j. neuint.2014.08.005)

Li JJ, Deng J, Sheng WL \& Zuo ZY 2012 Metformin attenuates Alzheimer's disease-like neuropathology in obese, leptin-resistant mice. Pharmacology, Biochemistry, and Behavior 101 564-574. (https:// doi.org/10.1016/j.pbb.2012.03.002)

Li X, Wang Y, Wang K \& Wu Y 2018 Renal protective effect of paeoniflorin by inhibition of JAK2/STAT3 signaling pathway in diabetic mice. BioScience Trends 12 168-176. (https://doi.org/10.5582/ bst.2018.01009)

Li CD, Zhao JY, Chen JL, Lu JH, Zhang MB, Huang Q, Cao YN, Jia GL, Tao YX, Li J, et al. 2019 Mechanism of the JAK2/STAT3-CAV-1-NR2B signaling pathway in painful diabetic neuropathy. Endocrine $\mathbf{6 4}$ 55-66. (https://doi.org/10.1007/s12020-019-01880-6)

Livak KJ \& Schmittgen TD 2001 Analysis of relative gene expression data using real-time quantitative PCR and the 2(-Delta Delta C(T)) Method. Methods 25 402-408. (https://doi.org/10.1006/ meth.2001.1262)

Makar TK, Hungund BL, Cook GA, Kashfi K \& Cooper AJ 1995 Lipid metabolism and membrane composition are altered in the brains of type II diabetic mice. Journal of Neurochemistry 64 2159-2168. (https://doi.org/10.1046/j.1471-4159.1995.64052159.x)

Martorana F, Brambilla L, Valori CF, Bergamaschi C, Roncoroni C, Aronica E, Volterra A, Bezzi P \& Rossi D 2012 The BH4 domain of $\mathrm{Bcl}-\mathrm{X}(\mathrm{L})$ rescues astrocyte degeneration in amyotrophic lateral sclerosis by modulating intracellular calcium signals. Human Molecular Genetics 21 826-840. (https://doi.org/10.1093/hmg/ ddr513)

McCrimmon RJ, Ryan CM \& Frier BM 2012 Diabetes and cognitive dysfunction. Lancet 379 2291-2299. (https://doi.org/10.1016/S01406736(12)60360-2)

Naeve GS, Ramakrishnan M, Kramer R, Hevroni D, Citri Y \& Theill LE 1997 Neuritin: a gene induced by neural activity and neurotrophins that promotes neuritogenesis. PNAS 94 2648-2653. (https://doi. org/10.1073/pnas.94.6.2648)

Okada S, Hara M, Kobayakawa K, Matsumoto Y \& Nakashima Y 2018 Astrocyte reactivity and astrogliosis after spinal cord injury.

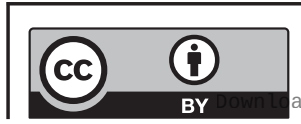

This work is licensed under a Creative Commons Attribution 4.0 International License. ded from Bioscientifica.com at 04/26/2023 11:20:05AM 
Neuroscience Research 126 39-43. (https://doi.org/10.1016/j. neures.2017.10.004)

Pekny M \& Pekna M 2014 Astrocyte reactivity and reactive astrogliosis: costs and benefits. Physiological Reviews 94 1077-1098. (https://doi. org/10.1152/physrev.00041.2013)

Porter WD, Flatt PR, Holscher C \& Gault VA 2013 Liraglutide improves hippocampal synaptic plasticity associated with increased expression of Mash1 in ob/ob mice. International Journal of Obesity 37 678-684. (https://doi.org/10.1038/ijo.2012.91)

Putz U, Harwell C \& Nedivi E 2005 Soluble CPG15 expressed during early development rescues cortical progenitors from apoptosis. Nature Neuroscience 8 322-331. (https://doi.org/10.1038/nn1407)

Robson MJ, Turner RC, Naser ZJ, McCurdy CR, O'Callaghan JP, Huber JD \& Matsumoto RR 2014 SN79, a sigma receptor antagonist, attenuates methamphetamine-induced astrogliosis through a blockade of OSMR/gp130 signaling and STAT3 phosphorylation. Experimental Neurology 254 180-189. (https://doi.org/10.1016/j. expneurol.2014.01.020)

Rodriguez JJ, Olabarria M, Chvatal A \& Verkhratsky A 2009 Astroglia in dementia and Alzheimer's disease. Cell Death and Differentiation 16 378-385. (https://doi.org/10.1038/cdd.2008.172)

Rossi D, Brambilla L, Valori CF, Roncoroni C, Crugnola A, Yokota T, Bredesen DE \& Volterra A 2008 Focal degeneration of astrocytes in amyotrophic lateral sclerosis. Cell Death and Differentiation 15 1691-1700. (https://doi.org/10.1038/cdd.2008.99)

Santello M, Toni N \& Volterra A 2019 Astrocyte function from information processing to cognition and cognitive impairment. Nature Neuroscience 22 154-166. (https://doi.org/10.1038/s41593-0180325-8)

Sharma TP, Liu Y, Wordinger RJ, Pang IH \& Clark AF 2015 Neuritin 1 promotes retinal ganglion cell survival and axonal regeneration following optic nerve crush. Cell Death and Disease 6 e1661. (https:// doi.org/10.1038/cddis.2015.22)

Shentu YP, Hu WT, Zhang Q, Huo Y, Liang JW, Liuyang ZY, Zhou H, Wei H, Ke D, Wang XC, et al. 2019 CIP2A-promoted astrogliosis induces AD-like synaptic degeneration and cognitive deficits. Neurobiology of Aging 75 198-208. (https://doi.org/10.1016/j. neurobiolaging.2018.11.023)

Sheppard MC, Bailey CJ, Flatt PR, Swanston-Flatt SK \& Shennan KI 1985 Immunoreactive neurotensin in spontaneous syndromes of obesity and diabetes in mice. Acta Endocrinologica 108 532-536. (https://doi. org/10.1530/acta.0.1080532)

Shimada T, Yoshida T \& Yamagata K 2016 Neuritin mediates activitydependent axonal branch formation in part via FGF signaling. Journal of Neuroscience 36 4534-4548. (https://doi.org/10.1523/ JNEUROSCI.1715-15.2016)

Si Y, Zhang Y, Han L, Chen L, Xu Y, Sun F, Ji M, Yang J \& Bao H 2016 Dexmedetomidine acts via the JAK2/STAT3 pathway to attenuate isoflurane-induced neurocognitive deficits in senile mice. PLOS ONE 11 e0164763. (https://doi.org/10.1371/journal.pone.0164763)

Sima AA 2010 Encephalopathies: the emerging diabetic complications. Acta Diabetologica 47 279-293. (https://doi.org/10.1007/s00592-0100218-0)

Son H, Banasr M, Choi M, Chae SY, Licznerski P, Lee B, Voleti B, Li N, Lepack A, Fournier NM, et al. 2012 Neuritin produces antidepressant actions and blocks the neuronal and behavioral deficits caused by chronic stress. PNAS 109 11378-11383. (https://doi.org/10.1073/ pnas.1201191109)

Stranahan AM, Norman ED, Lee K, Cutler RG, Telljohann RS, Egan JM \& Mattson MP 2008 Diet-induced insulin resistance impairs hippocampal synaptic plasticity and cognition in middle-aged rats. Hippocampus 18 1085-1088. (https://doi.org/10.1002/hipo.20470)

Su YT, Meng XX, Zhang X, Guo YB, Zhang HJ, Cheng YP, Xie XP, Chang YM \& Bao JX 2017 Doxepin mitigates noise-induced neuronal damage in primary auditory cortex of mice via suppression of acid sphingomyelinase/ceramide pathway. Printed in Great Britain
Anatomical Record 300 2220-2232. (https://doi.org/10.1002/ ar.23677)

Subramanian J, Michel K, Benoit M \& Nedivi E 2019 CPG15/neuritin mimics experience in selecting excitatory synapses for stabilization by facilitating PSD95 recruitment. Cell Reports 28 1584-1595.e5. (https://doi.org/10.1016/j.celrep.2019.07.012)

Tang Y, Cai X, Zhang H, Shen H, Wang W, Shen Z, Gu W, Ling C \& Li M 2017 miR-212 mediates counter-regulation on CRH expression and HPA axis activity in male mice. Journal of Molecular Endocrinology 59 365-375. (https://doi.org/10.1530/JME-17-0124)

Tomassoni D, Nwankwo IE, Gabrielli MG, Bhatt S, Muhammad AB, Lokhandwala MF, Tayebati SK \& Amenta F 2013 Astrogliosis in the brain of obese Zucker rat: a model of metabolic syndrome. Neuroscience Letters 543 136-141. (https://doi.org/10.1016/j. neulet.2013.03.025)

van Agtmaal MJM, Houben AJHM, de Wit V, Henry RMA, Schaper NC, Dagnelie PC, van der Kallen CJ, Koster A, Sep SJ, Kroon AA, et al. 2018 Prediabetes is associated With structural brain abnormalities: the Maastricht study. Diabetes Care 41 2535-2543. (https://doi. org/10.2337/dc18-1132)

Vannucci SJ, Gibbs EM \& Simpson IA 1997 Glucose utilization and glucose transporter proteins GLUT-1 and GLUT-3 in brains of diabetic (db/db) mice. American Journal of Physiology 272 E267-E274. (https://doi.org/10.1152/ajpendo.1997.272.2.E267)

Wang K, Wu YG, Su J, Zhang JJ, Zhang P \& Qi XM 2012 Total glucosides of paeony regulates JAK2/STAT3 activation and macrophage proliferation in diabetic rat kidneys. American Journal of Chinese Medicine 40 521-536. (https://doi.org/10.1142/S0192415X12500401)

Wang H, Li X, Shan L, Zhu J, Chen R, Li Y, Yuan W, Yang L \& Huang J 2016 Recombinant hNeuritin promotes structural and functional recovery of sciatic nerve injury in rats. Frontiers in Neuroscience $\mathbf{1 0}$ 589. (https://doi.org/10.3389/fnins.2016.00589)

Wanner IB, Anderson MA, Song B, Levine J, Fernandez A, GrayThompson Z, Ao Y \& Sofroniew MV 2013 Glial scar borders are formed by newly proliferated, elongated astrocytes that interact to corral inflammatory and fibrotic cells via STAT3-dependent mechanisms after spinal cord injury. Journal of Neuroscience 33 12870-12886. (https://doi.org/10.1523/JNEUROSCI.2121-13.2013)

Xi C, Zhang Y, Yan M, Lv Q, Lu H, Zhou J, Wang Y \& Li J 2020 Exogenous neuritin treatment improves survivability and functions of Schwann cells with improved outgrowth of neurons in rat diabetic neuropathy. Journal of Cellular and Molecular Medicine $\mathbf{2 4}$ 10166-10176. (https://doi.org/10.1111/jcmm.15627)

Xu Y, Zhou H \& Zhu Q 2017 The impact of microbiota-gut-brain axis on diabetic cognition impairment. Frontiers in Aging Neuroscience 9106. (https://doi.org/10.3389/fnagi.2017.00106)

Yan BB, Li LH, Harden SW, Epstein PN, Wurster RD \& Cheng ZJ 2009 Diabetes induces neural degeneration in nucleus ambiguus (NA) and attenuates heart rate control in OVE26 mice. Experimental Neurology 220 34-43. (https://doi.org/10.1016/j.expneurol.2009.07.006)

Yan W, Zhang M, Yu Y, Yi X, Guo T, Hu H, Sun Q, Chen M, Xiong H \& Chen L 2019 Blockade of voltage-gated potassium channels ameliorates diabetes-associated cognitive dysfunction in vivo and in vitro. Experimental Neurology 320 112988. (https://doi.org/10.1016/j. expneurol.2019.112988)

Yang M, Tian M, Zhang X, Xu J, Yang B, Yu J, Li F, Li Y, Li S \& Li X 2017 Role of the JAK2/STAT3 signaling pathway in the pathogenesis of type 2 diabetes mellitus with macrovascular complications. Oncotarget 8 96958-96969. (https://doi.org/10.18632/ oncotarget.18555)

Yermakov LM, Griggs RB, Drouet DE, Sugimoto C, Williams MT, Vorhees CV \& Susuki K 2019 Impairment of cognitive flexibility in type 2 diabetic db/db mice. Behavioural Brain Research 371111978. (https://doi.org/10.1016/j.bbr.2019.111978)

Yuan XY \& Wang XG 2017 Mild cognitive impairment in type 2 diabetes mellitus and related risk factors: a review. Reviews in the

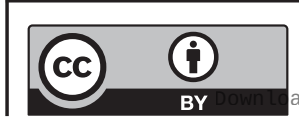

This work is licensed under a Creative Commons Attribution 4.0 International License. ded from Bioscientifica.com at 04/26/2023 11:20:05AM 
Neurosciences 28 715-723. (https://doi.org/10.1515/ revneuro-2017-0016)

Zhang QJ, Li J \& Zhang SY 2018 Effects of TRPM7/miR-34a gene silencing on spatial cognitive function and hippocampal neurogenesis in mice with type 1 diabetes mellitus. Molecular Neurobiology 55 1568-1579. (https://doi.org/10.1007/s12035-017-0398-5)

Zhao JJ, Hu JX, Lu DX, Ji CX, Qi Y, Liu XY, Sun FY, Huang F, Xu P \& Chen XH 2017 Soluble cpg15 from astrocytes ameliorates neurite outgrowth recovery of hippocampal neurons after mouse cerebral ischemia. Journal of Neuroscience 37 1628-1647. (https://doi. org/10.1523/JNEUROSCI.1611-16.2016)
Zhou S \& Zhou J 2014 Neuritin, a neurotrophic factor in nervous system physiology. Current Medicinal Chemistry 21 1212-1219. (https://doi. org/10.2174/0929867321666131218093327)

Zhou J, Du X, Long M, Zhang Z, Zhou S, Zhou J \& Qian G 2016 Neuroprotective effect of berberine is mediated by MAPK signaling pathway in experimental diabetic neuropathy in rats. European Journal of Pharmacology 774 87-94. (https://doi.org/10.1016/j. ejphar.2016.02.007)

Zhou J, Zhang Z, Zhou H \& Qian G 2020 Diabetic cognitive dysfunction: from bench to clinic. Current Medicinal Chemistry 27 3151-3167. (https://doi.org/10.2174/1871530319666190206225635)

Received in final form 13 February 2021

Accepted 16 March 2021

Accepted Manuscript published online 17 March 2021
This work is licensed under a Creative Commons Attribution 4.0 International License.

ded from Bioscientifica.com at 04/26/2023 11:20:05AM 